\title{
There's No Place Like a Refugee Camp? Urban Planning and Participation in the Camp Context
}

\author{
Anne Stevenson and Rebecca Sutton
}

\begin{abstract}
The past half-century of urban studies has demonstrated that the design of human settlements is a potent tool of governance. Active involvement in place shaping has also been shown to be a key empowerment mechanism for citizens and a strong means of creating cohesion in communities. Internally displaced persons (IDPs) and refugee camps are a unique form of human habitation, temporary spaces created "between war and city." Drawing from urban planning theory, camp management tools, and migrant narratives, this paper will explore the dynamics of the spatial relationship between camp residents and the international governance bodies who manage them. As we will demonstrate, this approach offers important insights into how the relationships between camp residents and aid agencies are negotiated, and the implications for governance in societies camp inhabitants later (re)settle in.
\end{abstract}

\section{Résumé}

Les études d'urbanisme des cinquante dernières années ont démontrés que la planification d'établissements humains est un outil potentiel de gouvernance. Il a été également montré que l'organisation active de l'espace peut être un mécanisme d'implication des citoyens et un moyen puissant de créer les cohésions communautaires. Les camps de personnes déplacées localement et de réfugiés sont une forme spécifique d'habitation humaine, correspondant à des espaces créés temporairement "à mi-chemin entre la ville et la guerre ». En se basant sur des théories de planification urbaine, des outils de gestion de camp, et des récits de migrants, cet article explore les dynamiques des relations spatiales entre les résidents de camp et les organisations gouvernementales internationales qui les gèrent. On y montre que cette approche permet de mieux saisir comment se déroule les relations entre les résidents de camp et les agences humanitaires, ainsi que les conséquences que cela implique pour la gouvernance des sociétés dans lesquelles s'installent ensuite ces résidents de camps.

... . it is possible to use the experiences in exile to transform a society as long as those who assist them do not remove from them the authority to do so.

-Barbara Harrell-Bond ${ }^{1}$

\section{Introduction}

The past half-century of urban studies has demonstrated that the design of human settlements is a potent tool of governance. The layout of the built environment is a primary mediator in people's access to services, feelings of safety and connection to the wider community. ${ }^{2}$ Active involvement in place shaping has also been shown to be a key empowerment mechanism for residents and a strong means of building citizenship. ${ }^{3}$ Internally displaced persons (IDPs) and refugee camps are a unique form of human habitation, temporary spaces created "between war and city" 4 that play a formative role in residents' migration story. ${ }^{5}$ However, in focusing on the protection and survival of inhabitants, the international agencies that run these camps rarely empower residents to act as citizens of them. ${ }^{6}$

Drawing from urban planning theory, camp management tools, and migrant narratives, this paper will explore the dynamics of the relationship between camp residents 
and the international governance bodies who manage them; particular scrutiny will be devoted to citizenship practices as they relate to the built environment of the camp. We will argue that the rights claims and service demands camp residents make, and how they negotiate their relationships with aid agencies and government are important: they impact migrant experiences in the camp itself, and may (re)shape expectations of governance in the societies they later settle in as they begin the process of rebuilding their lives.

A number of field manuals have been developed to guide the management of refugee and IDP camps, and three will form the basis of this analysis: the UNHCR's Handbook for Emergencies (the Handbook); the Shelter/MSF guide, Camp Planning Guidelines (the Guidelines); ${ }^{7}$ and the Norwegian Refugee Council's Camp Management Toolkit (the Toolkit). References to these documents will be used to illustrate current guidance on resident participation and spatial planning in camps, considered through the lens of urban planning theory.

\section{Basic Principles of Urban Planning}

Urban planning theory is, in its essence, the exploration of the relationship between people and the physical spaces around them. From the time of the emergence of the world's oldest cities in Mesopotamia roughly 4,500 years ago, there have been competing interpretations of the control and ownership of cities. The very origins of the word "city" capture this dynamic precisely: derived from the Latin civitas, cities have been seen as both places of state power (civilization) and shared purpose (citizenship).

The past century of urban planning has been witness to a shift between these two paradigms. In the early decades of the twentieth century, human settlements were dominated by the notion of city as civilization, where the structure of the city was imposed from the top down by civil engineers and technocratic planners. The emphasis on efficiency, function, and a rational approach to the city was embodied in the modernist movement and its most well-known champion, Le Courbusier. His notion of the house as a "machine for living" extended to his grand urban planning projects, including a master plan for downtown Paris (never implemented) and Chandigarh in India. The layout of streets and buildings was strictly aligned, based on logic visible only from the air. Each part of the city had a rigidly defined function in the system. Different uses, such as housing, office blocks, and industrial areas, were separated and kept at a prescribed distance from one another. With the planners' tight control of the built form, there was little room to consider how residents themselves might wish to inhabit their city spaces.
As time wore on, it became apparent that the modernist approach delivered little in terms of quality of life for urban dwellers. The strict segregation of uses inconvenienced people-the separation of housing from other city functions entailed travel to work, heralding the beginning of the commute. The modernist city also led to social isolation, as its inhabitants lacked opportunities to interact with others in spontaneous meetings. Roads were viewed as conduits for vehicles and pedestrians only, with little thought to the other functions of a street such as market place or a social gathering spot to meet with neighbours. This failure to capture the diversity of uses of different urban spaces is perhaps the most serious shortcoming of this approach, and modernism's failure to appreciate the complexity of the city led to growing criticism of the movement.

The writings of Jane Jacobs are emblematic of the challenge that began to be mounted against modernism in the 1960s. Jacobs questioned the aerial, omnipotent perspective of the modernist planner and instead began to explore cities from the bottom up, looking at how people actually used urban spaces. In observing her own neighbourhood, typically assumed to be "disorganized, inefficient, and economically backward," she found instead an intricately orchestrated ballet of the streets. This unplanned area of the city was rich, active, and safe, in stark contrast to the modernists' rigid structures that led only to "the mild

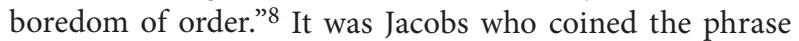
"eyes on the street," noting that residents acted as informal monitors for those around them, not only curbing dangerous behaviour, but creating a sense of belonging and community. She emphasized that the production of space was a potent embodiment of power relations, the built form being an explicit recognition of who made the decisions.

These observations informed the current canon of urban theory, where planning is not only about deciding where things should go, but also a process of education, engagement, and empowerment. In the same spirit of the UN's Local Agenda 21, ${ }^{9}$ the planning profession has increasingly shifted away from the top-down approach of the modernists towards a bottom-up, participatory, and citizenshipbased model for city design.

In this framework, participatory planning is a general process in which community members have an opportunity to act out their citizenship in decisions relating to the built environment. The Prince of Wales, a seemingly unlikely advocate of community empowerment, captures the underlying principle of this approach, stating that "people are not there to be planned for; they are there to be worked with."10 This approach might include city planners seeking input from the community about new buildings in their area, how a new housing development might be laid out, and even how 
neighbourhoods and cities should develop over a long period of time. In addition to any actual outcomes that result from these exercises, the process by which decisions are reached is increasingly recognized as significant.

A major, though somewhat counterintuitive, benefit of the participatory approach is that it can help create more efficient cities than the top-down approach. This is because communities can often identify their needs more accurately than a planner doing a technical assessment. For example, many municipalities have requirements for the amount of park space that should be provided per resident. Planners may be able to recognize a quantitative shortfall in park provision, but they are less capable of assessing qualitative deficiencies. Does the community need a quiet garden in which to sit and relax or an open field for sports and play? It has been shown that without residents' input, resources can be wasted on amenities that do not meet the needs of the community, consequently increasing the likelihood of these facilities being damaged or falling into disrepair.

In addition to creating an environment that is better suited to its residents, the evidence is overwhelming that participatory initiatives also have a positive social impact on those who engage in them. An early observer of this approach noted that "when dwellers control the major decisions and are free to make their own contribution ... both the process and the environment produced stimulate individual and social well-being."11 It is widely recognized that "when people feel they 'belong' to a neighbourhood which is theirs through their own efforts, then ... people will safeguard what they have helped to create." 12 Participatory planning has also been shown to be an important entry point for wider governance processes. As noted by one community member, "community planning gave us the opportunity to work alongside the powers that be, have our say and feel, for the first time, that we were really being listened to. Residents now feel much more connected with decision-making and things are really beginning to improve around here." 13

It is these insights from participatory urban planning that we wish to explore in the refugee or IDP camp context. The next section will examine the appropriateness of applying urban design theory to the camp context.

\section{Urban Planning and Refugee Camps: A Valid Theoretical Framework?}

Considerable debate surrounds the question of whether or not camps can be considered true "cities." If it were purely a matter of numbers, then in some places such as Chad and Darfur, camps would likely be viewed as urban-many of the IDP and refugee camps have greater populations than the towns and cities nearby. ${ }^{14}$ Yet population alone is not enough to convince actors that camps constitute true urban spaces.

An initial argument against viewing the camp as a city is the impermanence of its existence, a notion quite easily disproven. For example, the Camp Management Toolkit states, "Camps may be needed for only a matter of months. Often the reality is that camps last for years and sometimes even for decades." ${ }^{15}$ Explanations in mainstream media are similarly awkward: "Camps are only meant to be temporary solutions ... However, organizers have learned to plan for the long haul because refugees often end up living in the camps for much longer than expected."16 Indeed, the evidence shows overwhelmingly that protracted refugee situations remain the norm. ${ }^{17}$ A 2006 UNHCR report highlights that there are still over five million refugees in protracted situations, ${ }^{18}$ and camp-based population make up over 85 percent of today's refugees. ${ }^{19}$ Moreover, the average duration of stay in these protracted situations increased from 9 to 17 years from 1993 to $2003 .^{20}$

While a decade may seem inconsequential in a city's existence, it represents a transformational number of years in an individual's life. Children grow to be adults, people marry and procreate, the elderly pass on. A description of Kakuma refugee camp on the camp website runs as follows "Inside this small city at the edge of the desert, children age into adulthood and hope fades to resignation." ${ }^{21}$ We also hear a 70-year-old Bhutanese refugee describe his experience of raising eight children for 19 years in a camp in Nepal-a camp he says he will not leave even if he is the last man in it. ${ }^{22}$ These testimonies belie the notion that a camp is "temporary" in any practical way to its inhabitants. Camps constitute an enduring feature of the global order in general and the refugee experience in particular.

Camps are also often portrayed as extreme spaces. The focus is on the major events that give rise to the camps, the security threats that plague them, serious sanitation problems or outbreaks of communicable diseases. Yet many of the same individuals facing difficult conditions in the camp will have spent their entire lives enduring hardship in their communities of origin. This is not to downplay the very real threats to their security and well-being, but from the perspective of the individual or household in the camp-as with any village, city, or town - their location also plays host to the mundane. Drawing on Lefebvre's notion of social space, ${ }^{23}$ we contend that camps gain meaning as a place by acting as a backdrop to residents' lives, as they find ways to cope and adjust their own daily rituals, routines, and patterns to the camp setting.

No matter how contrived or ephemeral the settlements may be, the dynamic between residents and their physical environment will shape behaviours and outcomes within 
and beyond the confines of the camps. Consequently, we believe refugee and IDP camps are fertile ground for the application of urban design theory and that important insights in the management of camps can be gained through this approach.

\section{Current Practice in Camp Planning: Participation}

As outlined in Maslow's hierarchy of needs, physiological and safety needs are foundational and will often take precedence in a situation of crisis or insecurity. However, the hierarchy includes reference to individual needs of love and belonging, self-esteem, and self-actualization.

Given the limited resources available and the stated role of refugee camps, few would agree that it is the role of the camp to provide "love" for its inhabitants, or to help people "reach their full potential." However the essential point to take from Maslow's hierarchy is a recognition of the latent desire of individuals to participate in daily life, and the importance of the formation and maintenance of a com munity for individuals' sense of well-being. Without this meaningful participation, in the camp context there is a risk that the process by which basic care and protection are provided may lead inhabitants to feel disempowered, alienated, disrespected, and resentful.

In Imposing Aid, Barbara Harrell-Bond asserts that camps induce a sense of powerlessness and despair, which, as others have noted, is often interpreted by aid organizations as dependency and laziness. ${ }^{24}$ It has also been widely noted that if not exerting any real influence over their space, inhabitants will likely feel quite passive in the camp, as though it is a place not formed by them but rather that happens to them, a place they must adapt themselves to in order to access services and meet their needs. As Zetter remarks of refugee behaviour in the host society, they must acquiesce, at least to some degree, to their bureaucratic identity in order to secure access to benefits and protection. ${ }^{25}$

Encouragingly, the importance of participation is highlighted in camp guidance documents. Of the three analyzed here, namely the Handbook, the Guidelines, and the Toolkit, each gives consideration to the important role of participation in the camp context. The Handbook and Toolkit consistently emphasize the importance of community involvement in camp planning and management as a means of ensuring the self-respect of individuals in the camps. The Toolkit expresses this perhaps most clearly: "whilst there is no universally accepted concept of the term dignity, in practice, it means that the thoughts and wishes of displaced communities are respected." 26

The Toolkit also stresses that interventions should build on local capacity without undermining people's own coping strategies. The Handbook similarly notes the management “plan must strengthen the refugees' own resources and selfreliance and avoid creating dependency." 27 While the guidance on camp resident involvement in the Guidelines is not detailed, it does extol the importance of maximizing the participation of the displaced population in camp management and maintenance ${ }^{28}$ and stresses the need to identify existing coping strategies of the camp residents. ${ }^{29}$ Emphasis is also placed on the need to facilitate true participation, rather than mere consultation. As put so aptly by the Toolkit, "the ultimate goal of participation is a feeling of ownershipthat residents feel they are investing in, and responsible for, the camp and the activities that take place within it."30

As the brief overview above indicates, the camp guidance documents and the broader literature acknowledge the risks of disempowering camp inhabitants and the importance of ensuring genuine participation. However, the language employed to describe and refer to the identity of these inhabitants often seems incompatible with genuine empowerment. In aid literature, we find businesslike references to the camp's "clients" and "end-users" 31 or, as noted by Goodwin-Gill, the rather statistical descriptors of "units of flight" or "units of displacement." 32 Both the Handbook and the Guidelines refer to camp inhabitants variously as "persons of concern," "refugee community members," "displaced population," and similar variations on this theme. The Toolkit alone consistently refers to individuals as residents of the camp, explicitly recognizing their status as users and inhabitants of the camp space.

Within this myriad of labels, one that is never used is "citizens" of the camps. While this is to some extent logical given their displacement and, in the case of refugees, their legal status in the host country, it stifles thinking about what kind of substantive participation might be possible in camps. This is not merely an issue of semantics: the formulation of the (ascribed) identity of camp inhabitants has crucial implications for whether the practice on the ground reflects-or could reflect-the theory regarding camp participation. Indeed, by looking at the guidance for the physical layout of the camp, we see evident limits to the genuine involvement of residents in the shaping of their communities. As the next section explores, the concept of participation is not consistently or successfully integrated into guidance on the spatial planning of camps.

\section{Current Practice in Camp Planning: Built Environment}

Literature specifically focused on the physical planning of refugee camps is limited, but a notable commentator on the current approach is Herz. There are some limitations in his analysis, specifically his incorrect statement that the 
Handbook's single chapter is the only guide for spatial planning in camps. His assertion that the physical planning guidance "largely ignores the social and political consequences that planning decisions have in this critical context" also seems misplaced, as there is in fact clear recognition throughout all three guidance documents that "the physical organization of the settlement will markedly affect the protection, health and well being of a community." 33 Yet Herz's general point is a valid one, as all three guidance documents fail to graft their notions of community involvement effectively onto processes surrounding the creation of the built environment.

Herz observes that the prescribed camp layouts are suggestive of the "early modernist idealized city of the 1920s: structured organization, low density, clear separation of functions and uses." This is certainly reflected in the three guidance documents in question. For example, the Handbook recommends the development of a camp master plan, which is intended to take physical factors, like climate, topography, and safety, into account when laying out the camps. It recommends building on the basic unit of the family, where 16 households create one community, 16 communities create one block, four blocks make one sector, and four sectors a camp. The ideal population is seen as being 20,000 people with 30 to 45 square metres per individual.

The Toolkit largely echoes the Handbook formula for camp set-up, following the community/block/sector/camp approach, and also stresses 20,000 as an optimal number of residents per camp. ${ }^{34}$ The Shelter/MSF Guidelines go the furthest in exploring different spatial organizations for camps. Building on the Handbook's community structure of roughly 16 family units per community, the Guidelines then go on to provide three different layouts for the community block, including the Hollow Square Plan, the Staggered Plan, and the Community Road Plan. ${ }^{35}$

What is noticeable in all three guidance documents is the perspective of the camp is a decidedly modernist, aerial view, planned from above both literally and figuratively. Even the Guidelines, with their more nuanced and adaptable approach to site planning, still ultimately present a uniform and relatively inflexible framework; plots are identically sized, streets are gridded, and only residential uses are spatially planned for at the block level.

It is interesting to note that the smallest unit of planning in all three guidance documents is consistently conceptualized as the family unit, rather than the individual. While there is certainly some justification for this, it begs the question of how camps are physically designed for those individuals who do not fit into a traditional family grouping. The Handbook notes the high prevalence of unaccompanied minors or lone elderly that are often present in the camp. ${ }^{36}$
Basing physical planning around the family unit literally leaves no space in the camp for those who do not fit the family model.

The Toolkit acknowledges this problem and stresses that it is generally inadvisable to locate lone individuals apart from the rest of the community as "it isolates these groups and leaves them without the protection of the community at large." 37 The Handbook also recognizes this challenge, noting for example that unaccompanied older people are often put into tents with strangers due to the common practice of assigning five people per tent. ${ }^{38}$ However, no satisfying spatial solution is provided to this problem.

Further to this point, the guidance documents are generally silent on how plots are allocated. The Handbook refers to "allocating tent/shelter plots in the camp" during registration, ${ }^{39}$ but it remains unclear what factors might influence decisions around allocation. It has been noted that practical measures like keeping village units together in a camp setting could play a major role in social cohesion, and are more useful than disease or trauma-centred approaches. ${ }^{40}$ Yet the guidance documents do not provide any clear instruction on how this might be facilitated in practice.

The guidance documents also reflect the modernist approach to planning in the strict zoning of different uses at the community level. Community layout grids contain only residential blocks and some essential services, such as water-taps and latrines. No spatial guidance is provided on the integration of schools, markets, and other communal facilities into the community blocks. Spaces for socialization and economic activity are mentioned in the guidance documents but not addressed in a spatial way beyond recommendations for garden plots that could be used for income generation.

The Guidelines ${ }^{41}$ and Toolkit ${ }^{42}$ both mention the informal services and facilities that often emerge in camps, noting for example that small community-level corner stalls may be established. These spontaneous elements, reminiscent of Jane Jacobs's “organized complexity," however, are unattended to in the modernist camp layout plan where each square metre appears tightly programmed. The guidance documents do not offer any advice about how these informal services might be spatially planned for or, more importantly, how camp communities might be encouraged to participate in their creation.

As an extension of the zoning aspects of modernist planning, major camp services in both the Handbook and Toolkit are envisioned in centralized compounds. It is recommended that each camp of 20,000 have one feeding centre and one market per camp. Health centres are also proportioned at one per camp. These recommendations appear at odds with the Handbook's explicit statement that "the 
overall physical layout of a site should reflect a decentralized community-based approach." 43 While both schools and distribution points are provided in a slightly more dispersed manner, there is little visible evidence of a decentralized approach in guidelines for the physical form of the camp.

A likely reason for this inclination towards consolidated services can be found in the Handbook's stated benefit of planned communities: "services can be provided to a large population in a centralized and efficient way." 44 The question is, for whom is this centralization efficient, the residents or the agencies who manage them? There in fact seems to be an insistence on separating resources from inhabitants. As mentioned in one source, warehouses should be located near administrative centres for security reasons, preferably "near the entrance of the camp so supply trucks do not have to drive through populated areas." 45 As noted by Herz, "the actual physical spaces where humanitarian aid is provided in the camps, such as medical centers, are located at a distance from the refugees, to make for an easy escape, in case the refugees should start an unrest." 46

In keeping with Jane Jacobs's notion of eyes on the street, the Handbook points out that isolated areas create safety concerns in the camp, specifically for the most vulnerable inhabitants. This public security mechanism is alluded to frequently in the guidance documents. For instance, a justification for one community layout in the Guidelines is that "providing access to family plots via semi-private roads will facilitate casual "neighbourhood watch," thus increasing security." 47 This logic, however, is not carried over to the broader camp context to consider how adjacent residents might overlook, and consequently protect, communal service areas. Given that a main aim of the camp setting is to provide safety for inhabitants, this is an unfortunate result.

The centralized provision of major services also undermines a core value expressed by the guidance documents, that of equal access for all. Individuals who have to walk further to reach services inevitably have less access to them. The Toolkit notes this almost accidentally: "Camp communities situated near centralised facilities will have more traffic. Other areas will feel isolated and have a greater turnover in population or more abandoned shelters." ${ }^{4}$ The latter statement is particularly striking from an urban planning perspective. It recognizes that proximity to services has an impact on the desirability of the shelters in that area and that residents enjoy different benefits depending on their location in the camp. Despite this, there is no corresponding consideration on how the layout could be adapted to reduce these isolated areas.

The Guidelines take a less prescriptive approach to the location and provision of major services, noting that warehouses may be located centrally or dispersed around the camp. While this approach to spatial planning is more flexible, there is no mention of involving residents in these decisions. This weakens the credibility of recommendations made elsewhere in the guide that residents should be active participants in the running and management of their community. If they have no say in how these major services are provided, how much control can they actually exert?

There appears to be correspondingly little agency accorded to residents when it comes to selecting their location in the camp. Plots are simply allocated to new arrivals, with no suggestion that people could make this choice themselves. This omission is particularly striking given the Guidelines' recommendation to "avoid making decisions and performing tasks that could be handled by the community." 49 There is some irony in the failure to democratize a process that elsewhere occurs (at least in its early stages) spontaneously in the complete absence of aid agencies and the international community.

Table 1. From Norwegian Refugee Council, Camp Management Guidelines, 81

\begin{tabular}{|c|c|}
\hline $\begin{array}{c}\text { Degree of } \\
\text { Participation }\end{array}$ & Definition \\
\hline Ownership & $\begin{array}{l}\text { The community controls decision } \\
\text { making. }\end{array}$ \\
\hline Interactive & $\begin{array}{l}\text { The community is wholly involved in } \\
\text { decision making with other actors. }\end{array}$ \\
\hline Functional & $\begin{array}{l}\text { The community fulfils only a par- } \\
\text { ticular role with limited decision- } \\
\text { making power (for example, } \\
\text { forming a water committee which } \\
\text { is then supervised by an NGO staff } \\
\text { member). }\end{array}$ \\
\hline Material Motivation & $\begin{array}{l}\text { The community receives goods or } \\
\text { cash in return for a service or role. }\end{array}$ \\
\hline Consultation & $\begin{array}{l}\text { The community is asked for their } \\
\text { opinion on what they would like to } \\
\text { see, but their opinion has limited } \\
\text { sway in decision-making. }\end{array}$ \\
\hline Information Transfer & $\begin{array}{l}\text { Information is gathered from the } \\
\text { community, but they are not } \\
\text { involved in the resulting discus- } \\
\text { sions which inform decisions. }\end{array}$ \\
\hline Passive & $\begin{array}{l}\text { The community is informed of deci- } \\
\text { sions and actions, but have no say } \\
\text { in either the process or the result. }\end{array}$ \\
\hline
\end{tabular}

Because of these and other omissions, it remains unclear how the participation envisioned by the guidance documents is enacted on the ground. By the Toolkit's own standards (shown in Table 1) the participation recommended in the built environment-the most visible and tangible 
structure of the camp-would only rank at the "passive" level. The community has no say.

What are the implications of this? As noted earlier, from an urban planning perspective disassociation from the physical environment also means alienation from a central part of the social life of the community. Additionally, we would assert that there are significant implications in individuals' experiences beyond the confines of the camp. In her study of Kakuma and Dadaab refugee camps in Kenya, Napier-Moore finds that the relationships between refugees and governance bodies such as UNHCR and state government in camps are somewhat rigid, and also significant in shaping migrant expectations. These relations, she contends, "create a trajectory for similar future relations" 50 between the residents and future governing bodies. Building on this idea of a trajectory we contend that if left passive in major decisions that impact their surroundings in the camp, displaced individuals may find themselves again disempowered after leaving the camp, lacking the skills to change their situation. Conversely, active engagement in camp planning constitutes a learning opportunity for residents, to be applied when negotiating with their fellow community members and governing bodies in their lives after the camps.

\section{Reasons for the Current Approach}

These potential opportunities for involvement in spatial planning must, of course, be considered in the context of the challenging realities that characterize camps. Even where service providers and aid agencies endeavour to transcend the typical "emergency action" mode, they may be subjected to any or all of the following constraints: pressure from donor agencies, resource scarcity, time limits, budget limits, and a poor understanding of the local context. These tangible limitations often push service providers to take a "deficit focused approach"51 emphasizing what is common or universal about the refugee experience. ${ }^{52}$ The reduction of human needs to compartmentalized data is also one way of managing competing demands. ${ }^{53}$ While this may be grounded in valid pragmatic concerns, it is antithetical to the notion of active participation.

Another reason for the status quo-and this relates closely to the role and function of refugee camps-is widespread discomfort with the durability of camps. As mentioned earlier in this paper, there is empirical evidence that clearly indicates the protracted nature of displacement and the length of stay in camps. However, camps continue to be framed as temporary spaces that simply go on for "much longer than expected." This rhetoric actually serves an important purpose: it simultaneously accommodates the needs of diverse parties. It enables agencies such as UNHCR to espouse a commitment to "durable solutions," it encourages host governments to allow the camp in the first place (as few would likely do so if it was announced from the outset that the camp might remain for decades), and it allows the state from which individuals have fled to maintain that the displaced will return home "soon," in the advent of peace or greater stability. Encouraging camp residents to become more invested in the structure of the camp would undermine these convenient positions.

At first glance, the notion of spatial governance presented below may seem to constitute a radical reconceptualization of refugee camps that directly conflicts with the status quo and its accompanying rhetoric. However, we maintain that it is merely an extension of existing guidance on participation, one that weds participation more concretely to the physical environment. In the following section we will explain how spatial governance has the potential to work within recognized confines, strengthen existing practice, and provide opportunities for improved governance following departure from the camp.

\section{Opportunities for Spatial Governance}

The theories around participatory planning referenced earlier articulate the fact that people will have a greater sense of ownership over parts of the built environment that they control or feel a part of. This is recognized explicitly in the Handbook, which talks about the benefits of having placebased necessities, particularly water-taps that are shared within a defined community group of 16 households. It is noted that "experience shows that water distribution to small, socially cohesive groups of eighty to 100 people considerably reduces water wastage and destruction of taps, standposts and concrete aprons." 54

While such dynamics are recognized, creating a sense of ownership on a wider scale may be difficult to envision. We offer a series of recommendations below that could be useful in implementing a more place-based approach to camp planning and management.

A first step would be consistently linking participation to specific spaces. The physical layout promoted by all three guidance documents results in arbitrary spatial divisions of communities, blocks, sectors, and overall camps. Arbitrary delineation is in no way unique to camp planning and is a regular facet of urban planning in most municipal administrative systems. But the guidelines largely miss the opportunity to maximize the benefits that these arbitrary divisions may have, namely as a decision making unit or basis for participation and community involvement.

In the guidance documents there is some recognition of the important role that spatially organized participation can play. The Toolkit notes that, in the absence of traditional structures, "it is helpful to [organize people] by having 
geographic block or sector leaders. For very large camps, it may be necessary to encourage several hierarchical tiers (for example, having community, block and sector leaders)." 55 This astute observation goes no further, however. While the Toolkit mentions consultation with focus groups, camp committees, and special interest groups, there is no clear mechanism for consulting with a physically-based com munity about issues that are specific to the physical area they share. No reference is made to geographic groups as a valid category of consultation.

Similarly, the Handbook notes that representation should "be consistent with the physical divisions of the layout of the site." 56 Yet the guidance on distribution points for food and non-food materials suggests how little the community division is embedded in daily practice. The Handbook recommends a group-based distribution method, noting that the group usually consists of about 20 heads of family. This suggestion does not map onto the recommended physical infrastructure, which has communities composed of 16 households. If there is a reason why distribution could not be centred around the same community divisions created in the physical planning of the camp, it is not made clear. This is a missed opportunity, as aligning camp activities with a consistent physical grouping could build more of the sense of ownership and belonging. ${ }^{57}$ Reference to physical grouping would also help to set members of each group on equal footing, avoiding the pitfalls of organizing people exclusively according to their needs, deficiencies, and vulnerabilities. The latter approach sets residents up as victims rather than citizens with a stake in their community.

The above discussion may be considered as a "soft" approach to spatial governance; nothing on the ground is visibly changed, but the mechanisms of input have been shifted to consistently consider residents in relation to the space they inhabit. This can be considered the first order of spatial governance and roughly relates to bottom tier of degrees participation outlined in the Toolkit: "passive," "information," and "consultation." Going beyond this to a second order, we might delve deeper into how a sense of ownership could be fostered.

Decentralization of services could be a first element in this approach. As noted above, people felt a stronger sense of ownership and protection over community-based water points. This is illustrative of a well-documented phenomenon of people tending to care and connected more to amenities, places, and people that are physically close to them. With more, smaller distribution centres, people would have easier access to them and would likely feel a stronger sense of ownership. It would also provide opportunities for community members to work in those centres, resulting in more local control and, on a practical level, increased opportunities for volunteer or paid service-the latter relates to the "material motivation" degree of participation outlined in the Toolkit. One might argue that this would create more openings for clientelism or theft, processes which are well known to already occur in camps. On the contrary, we would argue that the more the community can feel ownership over the service, the more likely they are to respect and protect it from misuse.

Another step would be to have people involved in the layout and construction of their community, again with varying degrees as are practicably allowed. The Handbook recommends getting residents involved in the construction of their shelters where possible. ${ }^{58}$ We would stress the importance of this guidance point and would also suggest that this could also extend to the layout of the community. An excellent example of how this could be achieved comes from the architectural practice Elemental in Chile. Although more applicable for self-settled camps, it highlights how community involvement can contribute to ingenious solutions to resident needs.

The Chilean government tasked Elemental with rehousing 100 squatter families on the same 5,000 square-metre site they had been occupying for the past 30 years, an area known as Quinta Monroy. The architects worked with the community to come up with a plan for the space. While the aspiration among all residents was single-family, detached homes, it was recognized that this would mean only about 30 families would be able to remain on site. Rejecting this option, the community worked with Elemental to establish a set of guiding principles; all the families had to be accommodated on-site, everyone was to have direct street access (rather than a high-rise building) and housing units needed to be expandable and adaptable as families grew. The solution was a series of row houses that made efficient use of the site and met the guiding principles. Most striking about this project was its built-in capacity for personalization and adaptation. Rather than completed, fitted-out dwellings, the houses were rough shells that were eventually fitted out and expanded by the residents themselves. While driven by budgetary constraints, this led to diversity and a true sense of ownership among the residents.

This project is indicative of a degree of participation that the Toolkit would designate as "functional": even though the decision to build new houses was decided by the Chilean government, residents played an active role in shaping their new community. As with the paid service opportunities mentioned above, this type of involvement can also be understood in a "material motivation" degree of participation in the Toolkit. As noted in the Toolkit, "most people would rather spend their time looking for ways to support their own households, and for many camp residents this 
in itself is challenging enough." 59 It is through this type of active involvement that participation can result in direct benefits for participants-as well as the agencies that work with them-and make them more inclined to become and stay involved.

We might say the camp, as any city, is in a continual process of becoming. One of the most important, and also most challenging, functions of greater spatial governance in camps is therefore to facilitate opportunities for creating spaces that are truly flexible and adaptive to changing realities on the ground. There are ways for camp management organizations to plan, counterintuitively, for the sort of organized complexity purported by Jane Jacobs. This we might term the third order of spatial governance, and it requires governing bodies to consciously yield authority over the production of space, within certain proscribed limits.

An urban planning example of this approach comes from Colombia where Enrique Peñalosa, then the mayor of Bogota, recognized that the city was going to grow through the expansion of informal settlements. Rather than trying to control this process through land allocation or mass public housing construction, Peñalosa instead made the strategic decision to install essential infrastructure that informal settlers could build around. A pedestrian and biking highway was constructed out into the undeveloped fields where expansion was expected. As people began building out their community, it grew around the pre-placed highway, ensuring this essential piece of infrastructure was integrated into an otherwise unplanned community. This approach allowed residents control over the development of their community while still ensuring key services were provided.

A similar model could be contemplated in the camp context. Rather than marking out plots, camp planners could put in the main infrastructure (standpipes), set certain parameters (for example, the number of people "belonging" to a standpipe), and then allow camp residents to make the detailed decisions on layout. This method would be very much in keeping with the Toolkit's highest level of participation where the community controls the decision making. In addition to creating a strong sense of ownership, this method has the potential to be more efficient; rather than rigid plots being provided for any shape and size of family, units could be more appropriately delineated according to the individuals and their needs.

This more extreme approach is open to challenge on a number of fronts. As camps are usually settled in waves, there may not be a conveniently community-sized group arriving all at once to plan their 16-family area in the camp. More likely, residents who arrived early would claim more of the allotted space, leaving late-comers with little room to be accommodated. There could also be concerns that marginalized groups would be unable to claim adequate space and would be relegated insufficient space for their accommodation. These are all possible, if not likely scenarios, in the camp setting, and yet they are not unique to it. Access to resources-including land-is a process that is constantly negotiated in societies and constitutes an important forum for civil engagement.

Wilson and Harrell-Bond assert that camps should focus on facilitating people's coping strategies ${ }^{60}$ and the planning process provides a unique opportunity to increase individual and group decision-making structures. We would offer that instead of devoting energy to dictating the spatial layout of communities, camp management organizations could instead provide the skills for communities to resolve these issues for themselves. Like the Quinta Monroy example above, urban planning practice is replete with examples of communities successfully managing the responsibility of spatial planning, even in the most trying of situations. Granted, this is not without training, facilitation, defined dispute resolution mechanisms, and clear parameters of involvement, but experience shows that people can resolve complex planning issues together, and gain a sense of ownership and empowerment in the process.

We recognize that in some cases, expediency will necessitate a more structured approach to camp planning, but we maintain that there may still be opportunities for more active place shaping, even within the stricter limitations of the prescribed grid layouts provided in the guidance documents. For example, one corner plot in each 16-family grouping could potentially be left unprogrammed for the community to decide what to do with. An initial objection to this approach might be that a single individual or family will simply annex any leftover space for their own use. Yet evidence from informal settlements around the world suggests this would not necessarily be the case. It is typical to find a large tract of open land in an otherwise densely packed development. In an absence of planning authorities, these self-organized communities have collectively maintained these spaces for football pitches. Rather than exploiting it to their individual advantage, residents protect this space in recognition of its communal value.

A question naturally emerges here regarding the potential consequence of a successful spatial governance approach. If people feel such a strong sense of ownership over their space in the camp, might they be reluctant to give it up, thus generating even more protracted camp situations? We would argue that spatial governance has as much potential to strengthen return or resettlement plans as it does to weaken them. The Toolkit asserts that participation "develops skills for life after displacement." 61 The need for rebuilding both 
physical and social structures is something that virtually all returning communities will likely face on their homecoming, and unlikely with a strong government or NGO to support this process. Providing residents with spatial planning skills while in the camp will better equip them for their return.

The Toolkit suggests reconnaissance missions, or "Go and See visits," where camp residents are able to return to their place of origin and report back conditions to the rest of the camp. These visits could be extended to include a more targeted spatial audit where participants document which structures are still standing, how much needs to be rebuilt, and what services and facilities are still available. This information could then be shared with the displaced community and workshops could be held to determine planning and rebuilding priorities.

Gaventa claims that "power gained in one space, through new skills, capacity and experiences, can be used to enter and affect other spaces." 62 We would argue that if spatial planning can create a sense of belonging in the camps, it may also allow residents to become (re-)invested in the places they are returning to. In particular, if camp residents can consistently feel that the quality of their camp community is the result of their own work, it may give them the confidence that they can achieve a similarly positive impact in their places of origin or places of resettlement. This is why the impact of participation and empowerment in the camp context is significant and far-reaching.

\section{Conclusion}

A key aim of this paper has been to formulate a framework for discussion and dialogue around camp planning that is informed by an urban planning perspective. While our conclusions are necessarily partial and tentative, our aim has been to suggest ways in which participation might be more thoroughly and explicitly embedded in the physical aspects of camp planning. We have endeavoured here to reconceptualize the physical planning and operation of camps into a more spatial and participatory process. In doing so, we have attended not only to the physical structures, but also the decision-making structures and processes by which "facts" are created on the ground. Reconsidering the built environment of the camp and the provision of services along these lines is, we submit, essential. Without a stronger commitment to spatial governance, the entreaties in the guidance documents to respect the dignity of residents and promote their sense of ownership in the camp will continue to ring somewhat hollow.

\section{Notes}

1. Barbara Harrell-Bond, Imposing Aid: Emergency Assistance to Refugees (Oxford: Oxford University Press, 1986), 1-469.

2. Jane Jacobs, The Death and Life of Great American Cities (New York: Random House, 1961), 1-458; J. L. Nasar and B. Fisher, "Design for Vulnerability: Cues and Reactions to Fear of Crime," Sociology and Social Research 76, no. 2 (1992): 48-58.

3. James Holston, Insurgent Citizenship: Disjunctions of Democracy and Modernity in Brazil (Princeton: Princeton University Press, 2008), 1-416; Susan Bickford, "Constructing Inequality: City Space and the Architecture of Citizenship," Political Theory 28, no. 3 (June 2008): 355-76.

4. Michael Agier, "Between War and City: Towards an Urban Ethnography of Refugee Camps," Ethnography 3 (2002): 317-41.

5. Rebecca Napier-Moore, "Entrenched Relations and the Permanence of Long-Term Refugee Camp Situations" (working paper no. 28, University of Sussex, 2005): 1-21.

6. Katarzyna Grabska, "Who Asked Them Anyway? Rights, Policies and Wellbeing of Refugees in Egypt" (research report, Development Research Centre on Migration, Globalization and Poverty, Brighton, July 2006); http:// www.migrationdrc.org/publications/research_reports /Kasia_Egypt_Research_ReportEDITED.pdf; see also Rebecca Sutton, "Are We Doing Things Right? Are We Doing the Right Things? Looking for Answers in Darfur," Ontario Council for International Cooperation $i A M$ e-magazine 2 (March 2011), http://content.yudu.com /Library/A1rqt5/iAMeMagazineVol2/resources/index.htm ?referrerUrl=http\%3A\%2F\%2Fwww.ocic.on.ca\%2FPage .asp\%3FIdPage\%3D9253.

7. The version of the Guidelines used is the 2008 draft version. We were not able to obtain a completed copy.

8. Max Page and Timothy Mennel, Reconsidering Jane Jacobs (Chicago: American Planning Association, 2011): 8.

9. United Nations, "Core Publications: Agenda 21," Principle 10, Chapter 28 (UN Division for Sustainable Development, 2009).

10. HRH The Prince of Wales, A Vision of Britain: A Personal View of Architecture (London: Doubleday, 1989), 1-160.

11. John F. C. Turner and R. Fichter, Freedom to Build: Dweller Control of the Housing Process (New York: Macmillan, 1972), 1-228.

12. Lord Scarman and Tony Gibson, "Neighbours in Crisisand Opportunity," The Guardian, December 11, 1991.

13. Nick Wates, ed., The Community Planning Handbook: How People Can Shape Their Cities, Towns and Villages in Any Part of the World (London: Earthscan, 2006), i.

14. "Planning Refugee Camps," Making Sense of Sudan, Manuel Herz, April 11, 2009, http://blogs.ssrc.org /sudan/2009/04/11/planning-refugee-camps/.

15. Norwegian Refugee Council, Camp Management Guidelines (Oslo: Camp Management Project, 2008), 2. 
16. "Anatomy of a Refugee Camp," CBC News in Depth, June 17, 2007, http://www.cbc.ca/news/background/refugeecamp/.

17. United Nations, "Protracted Refugee Situations: Millions Caught in Limbo with No End in Sight," 10 Stories the World Should Hear More About (2006), http://www.un.org /events/tenstories/06/story.asp?storyID=2600.

18. Ibid.

19. Agier, Between War and City, 318 .

20. Napier-Moore, "Entrenched Relations and the Permanence of Long-Term Refugee Camp Situations," 3.

21. "About Kakuma Refugee Camp," Kakuma News ReflectorA Refugee Free Press, 2008, http://kakuma.wordpress.com /about-kakuma-refugee-camp/.

22. Danish Church Aid, "70-Year Old Refugee in Nepal: This Camp is My Home" (May 2010), http://www.danchurchaid .org/where_we_work/asia/nepal/read_more/70-year_old _refugee_in_nepal_the_camp_is_my_home.

23. Henry Lefebvre, The Production of Space (Oxford: Blackwell, 1991), 68-168.

24. David Keen, Complex Emergencies (Cambridge: Polity Press 2008), 127.

25. Roger Zetter, "Labeling Refugees: Forming and Transforming a Bureaucratic Identity," Journal of Refugee Studies 4, no. 1 (1991): 45.

26. Norwegian Refugee Council, Camp Management Guidelines, 212.

27. United Nations High Commission on Refugees, Handbook for Emergencies, 3rd ed. (Geneva: UNHCR, July 2007), 8.

28. Médecins Sans Frontières and Shelter Centre, Camp Planning Guidelines 07b (Incomplete draft distributed for comment at Shelter Meeting 07b: 15-16 November 2007), 12.

29. Ibid., 56 .

30. Norwegian Refugee Council, Camp Management Guidelines, 78.

31. See for example Ton de Clerk and Tim Nourse, "Developing Micro-Enterprise in Refugee Camps: ARC's Experience in West Africa," Humanitarian Exchange Magazine 28 (November 2004), http://www.odihpn.org/report.asp?id=2680.

32. Guy Goodwin-Gill, "Refugee Identity and Protection's Fading Prospect," in Refugee Rights and Realities: Evolving International Concepts and Regime, ed. Frances Nicholson and Patrick Twomey (Cambridge: Cambridge University Press, 1999), 246.

33. United Nations High Commission on Refugees, Handbook for Emergencies, 3rd ed., 215.

34. There appear to be some internal inconsistencies in how the space of the camp is conceptualized. The recommended space allocation for a complete camp of 20,000 is given as 35 to 45 square metres per person. The Handbook multiplies this out for us, providing a total area of 90 hectares for a full camp. This translates to a population density of 220 to 330 people per hectare, comparable to downtown Seoul at the lower end of the spectrum and Hong Kong at the upper extreme, making the ideal camp within the top five most densely populated urban areas in the world. And this is to be achieved with single-storey buildings only. Furthermore, the dimensions of an ideal camp are also given as roughly one kilometre by 0.9 kilometres wide, relating to a 9 -hectare site. Yet it is distinctly noted later on in the Handbook that no one should have to walk more than 5 kilometres to get to a distribution centre.

35. Médecins Sans Frontières and Shelter Centre, Camp Planning Guidelines 07b, 97-100.

36. United Nations High Commission on Refugees, Handbook for Emergencies, 3rd ed., 229.

37. Norwegian Refugee Council, Camp Management Guidelines, 203.

38. United Nations High Commission on Refugees, Handbook for Emergencies, 3rd ed., 198.

39. Ibid., 164.

40. Keen, Complex Emergencies, 133.

41. Médecins Sans Frontières and Shelter Centre, Camp Planning Guidelines 07b, 107.

42. Norwegian Refugee Council, Camp Management Guidelines, 206.

43. United Nations High Commission on Refugees, Handbook for Emergencies, 3rd ed., 213.

44. Ibid., 208.

45. "Anatomy of a Refugee Camp," CBC News in Depth, June 17, 2007, http://www.cbc.ca/news/background/refugeecamp/.

46. "Planning Refugee Camps," Making Sense of Sudan, Manuel Herz, April 11, 2009, http://blogs.ssrc.org /sudan/2009/04/11/planning-refugee-camps/.

47. Médecins Sans Frontières and Shelter Centre, Camp Planning Guidelines 07b, 92.

48. Norwegian Refugee Council, Camp Management Guidelines, 207.

49. Médecins Sans Frontières and Shelter Centre, Camp Planning Guidelines 07b, 56.

50. Napier-Moore, Entrenched Relations and the Permanence of Long-Term Refugee Camp Situations, 1-21.

51. Linda A. Camino and Ruth M Krulfeld, eds., Reconstructing Lives, Recapturing Meaning: Refugee Identity, Gender, and Cultural Change (Amsterdam: Gordon and Breach Publishers, 1994), xiii.

52. Pottier identifies several worrisome consequences of this homogenization in the case of Rwanda: the lack of recognition of skills of individual refugees, degradation by masses of inappropriate food, and a lack of appreciation of political divisions specific to location. See Johan Pottier, Re-Imagining Rwanda: Conflict, Survival and Disinformation in the Late Twentieth Century (Cambridge: Cambridge University Press, 2002), 143; James Hart, "Beyond Struggle and Aid: Children's Identities in a Palestinian Refugee Camp in Jordan," in Children and Youth on the Front Line: Ethnography, Armed Conflict and Displacement, ed. Jo Boyden and Joanna de Berry, (New York: Berghahn Books, 2004), 171.

53. Zetter, "Labeling Refugees," 44.

54. United Nations High Commission on Refugees, Handbook for Emergencies, $3^{\text {rd }}$ ed., 219. 
55. Norwegian Refugee Council, Camp Management Guidelines, 84.

56. United Nations High Commission on Refugees, Handbook for Emergencies, 3rd ed., 108.

57. "About Community Planning: Benefits," Community Planning, March 17, 2009, http://www.communityplanning. net/aboutcp/aboutcp.php.

58. United Nations High Commission on Refugees, Handbook for Emergencies, 3rd ed., 201.

59. Norwegian Refugee Council, Camp Management Guidelines, 94.

60. Barbara Harrell-Bond and Ken Wilson, 'Enhancing Refugee's Own Food Acquisition Strategies" (Oxford nutrition symposium, March 1991).

61. Norwegian Refugee Council, Camp Management Guidelines, 79.
62. John Gaventa, "Finding the Space for Change: A Power Analysis," Institute of Development Studies, IDS Bulletin 37, no. 6 (November 2006): 27.

Anne Stevenson is an urban planner with international experience in West Africa, the UK, and Canada. She currently lives and works in Edmonton, Alberta. Rebecca Sutton is the former in-country director of War Child Canada in Sudan. She is currently completing her law degree in Toronto.

An earlier version of this paper was presented at the International Association for the Study of Forced Migration (IASFM) Governing Migration conference in Kampala, Uganda, in July 2011. 